\title{
Pengaruh Corporate Social Responsibility dan Kinerja pada Nilai Perusahaan dengan Kepemilikan Asing sebagai Variabel Moderasi
}

\author{
Ni Made Muliastari Rahayu ${ }^{1}$ \\ I Gst Ayu Eka Damayanthi
}

${ }^{1}$ Fakultas Ekonomi dan Bisnis Universitas Udayana (Unud), Bali, Indonesia
email: muliastarir@gmail.com/ Tlp: +6287860442132
${ }^{2}$ Fakultas Ekonomi dan Bisnis Universitas Udayana (Unud), Bali, Indonesia

\begin{abstract}
ABSTRAK
Nilai perusahaan merupakan tujuan jangka panjang perusahaan. Manajer dituntut untuk membuat keputusan dengan mempertimbangkan kepentingan semua stakeholder. Perusahaan perlu memperhatikan faktor-faktor yang memengaruhi nilai perusahaan. Tujuan penelitian ini yaitu untuk mengetahui pengaruh corporate social responsibility disclosure dan kinerja keuangan pada nilai perusahaan dengan kepemilikan asing sebagai variabel moderasi. Objek dalam penelitian ini adalah perusahaan manufaktur yang terdaftar di BEI tahun 2014-2016. Sampel penelitian yang dipilih melalui nonprobability sampling adalah sebesar 30 perusahaan. Moderated Regression Analysis (MRA) digunakan untuk mendapatkan hasil analisis data. Hasil yang didapat yaitu corporate social responsibility disclosure berpengaruh positif pada nilai perusahaan. Kinerja keuangan tidak berpengaruh pada nilai perusahaan. Kepemilikan asing memperlemah pengaruh corporate social responsibility disclosure pada nilai perusahaan. Kepemilikan asing tidak memoderasi pengaruh kinerja keuangan pada nilai perusahaan.

Kata kunci: Corporate social responsibility disclosure, kepemilikan asing, kinerja keuangan, nilai perusahaan
\end{abstract}

\begin{abstract}
Firm value is a long-term goal of the company. Managers are required to make decisions taking into account the interests of all stakeholders. Companies need to pay attention to the factors that affect the firm value. The purpose of this study is to determine the effect of corporate social responsibility disclosure and financial performance on the firm value with foreign ownership as a moderation variable. The research object used is a manufacturing company registered in 2014-2016. The sample of research taken with nonprobability sampling method is 30 companies. Moderated Regression Analysis (MRA) is used to obtain the results of data analysis. The results obtained are corporate social responsibility disclosure positively affects the firm value. Financial performance has no effect on firm value. Foreign ownership weakens the effect of corporate social responsibility disclosure on firm value. Foreign ownership does not moderated the effect of financial performance on firm value.

Keyword: Corporate social responsibility disclosure, foreign ownership, financial performance, firm value
\end{abstract}

\section{PENDAHULUAN}

Pertengahan tahun 2015, pelaku pasar di Indonesia merasakan terjadinya penurunan tingkat perekonomian global. Terlebih lagi, Bank Sentral Amerika Serikat, yaitu The Fed menaikkan suku bunga yang menyebabkan nilai Dollar 
Ni Made Muliastari Rahayu dan I Gst Ayu Eka Damayanthi. Pengaruh ...

Amerika Serikat menguat, sehingga kurs Rupiah tertekan dan melemah terhadap Dollar AS. Situasi tersebut menyebabkan investor menjual saham-saham perusahaan Indonesia dan memindahkan dananya ke instrument yang bersifat safe heaven, seperti Dollar. Krisis ekonomi global yang berdampak di Indonesia menyebabkan kinerja perusahaan manufaktur mengalami penurunan karena melonjaknya harga bahan pokok sehingga perekonomian melemah akibat menurunnya daya beli masyarakat. Melihat keadaan tersebut, pemerintah membuat kebijakan ekonomi yang mengatur kemudahan berinvestasi dan mendirikan usaha di Indonesia, namun sebuah studi oleh Kamar Dagang Eropa (Eurocham) menyebutkan bahwa tingkat kepercayaan investor Eropa kepada Indonesia menurun karena masalah regulasi, birokrasi, dan kebijakan ketenagakerjaan saat berinvestasi di Indonesia (BBC.com). Fenomena tersebut menuntut perusahaan untuk memiliki kinerja dan citra yang baik agar nilai perusahaan dapat meningkat. Tinggi rendahnya nilai perusahaan terlihat dari tinggi rendahnya harga saham. Harga saham yang tinggi menunjukkan tingginya nilai perusahaan, sehingga kemakmuran pemegang saham semakin meningkat. Oleh karena itu, manajer diharapkan dapat meningkatkan kinerja perusahaan dan melaksanakan aktivitas yang dapat meningkatkan citra perusahaan.

Perusahaan manufaktur merupakan salah satu perusahaan yang merasakan dampak dari terjadinya krisis ekonomi global. Perusahaan harus melakukan suatu tindakan untuk mendapatkan kepercayaan investor kembali karena perusahaan manufaktur merupakan lahan yang strategis untuk berinvestasi, melihat pesatnya pertumbuhan penduduk dan perkembangan ekonomi di negara Indonesia. 
Sementara itu, perusahaan manufaktur dalam proses produksinya berhadapan langsung dengan alam sehingga memiliki kontribusi yang cukup besar dalam masalah polusi, limbah, keamanan produk, dan tenaga kerja. Pelaksanaan aktivitas pengelolaan lingkungan hidup serta pengungkapan keamanan produk sangat penting dilakukan untuk menjamin keselamatan dan memperoleh kepercayaan dari konsumen.

Setiap perusahaan diwajibkan untuk mempublikasikan laporan tahunan untuk menunjukkan kinerja dan tanggung jawab manajemen dalam mengelola sumber daya yang ada, serta sebagai pertimbangan pengambilan keputusan bagi pengguna laporan. Perusahaan dituntut untuk melakukan pengungkapan yang baik mengenai kondisi perusahaan yang sebenarnya. Pengungkapan laporan tahunan harus disertai dengan pengungkapan tanggung jawab sosial atau mengungkapkannya ke dalam laporan keberlanjutan secara terpisah. Perusahaan yang tidak mempublikasikan laporan tahunan atau terlambat mempublikasikan dalam kurun waktu yang telah ditentukan akan mengurangi manfaat dari laporan tersebut. Laporan tersebut mengandung informasi yang tidak relevan karena informasi kehilangan kapasitasnya untuk memengaruhi keputusan pengguna laporan. Publikasi laporan tahunan perusahaan menyajikan informasi sehingga dapat membantu stakeholder untuk mengetahui nilai perusahaan. Salah satu cara untuk dapat meningkatkan nilai perusahaan yaitu dengan memerhatikan dimensi sosial dan lingkungan hidup agar keberlangsungan perusahaan dapat terjamin. Saat ini semakin banyak perusahaan yakin bahwa kelangsungan hidup perusahaan 
Ni Made Muliastari Rahayu dan I Gst Ayu Eka Damayanthi. Pengaruh ...

tergantung pada baik buruknya kinerja sosial dan lingkungan perusahaan, disamping kinerja keuangan perusahaan (Aghashahi et al., 2013).

Corporate Social Responsibility (CSR) merupakan suatu program tanggung jawab perusahaan terhadap sosial dan lingkungan disekitar perusahaan. Pengungkapan CSR akan disajikan dalam laporan berkelanjutan yang dapat diterbitkan secara terpisah ataupun tergabung dalam laporan tahunan perusahaan. Melalui pengungkapan CSR, stakeholder dapat melihat perhatian dan tanggung jawab perusahaan terhadap sosial dan lingkungannya dalam menjalankan bisnis. Perusahaan yang mengungkapkan berbagai komponen mengenai kinerja lingkungan bertujuan untuk memperoleh reaksi positif dari masyarakat dan lingkungan sekitarnya (Hui dan Bowrey, 2008). Semakin luas pengungkapan CSR, maka semakin tinggi penilaian stakeholder terhadap perusahaan dikarenakan citra perusahaan semakin baik. Aktivitas CSR dipercaya dapat memberi keuntungan jangka panjang kepada perusahaan (Garret dan Heal, 2004). Putri (2016) memperoleh hasil tanggung jawab sosial perusahaan berpengaruh positif terhadap nilai perusahaan, sedangkan Ghaesani (2016) menyatakan bahwa CSR tidak memengaruhi nilai perusahaan.

Kinerja keuangan yang ditunjukkan oleh besarnya laba perusahaan juga menjadi pertimbangan para stakeholder sebelum mengambil keputusan. Investor dalam memprediksi harga saham akan menilai faktor fundamental perusahaan yang meliputi kineja keuangan perusahaan. Salah satu cara menilai sebuah perusahaan adalah dengan melakukan pengukuran kinerja keuangan. Pengkuran kinerja keuangan dapat menggunakan analisis rasio, salah satunya yaitu rasio 
profitabilitas. Rasio profitabilitas memperlihatkan tinggi rendahnya laba yang dihasilkan perusahaan selama periode tertentu. Laba merupakan salah satu elemen dalam menciptakan nilai perusahaan. Return on Assets (ROA) merupakan salah satu rasio profitabilitas yang mengukur kemampuan dari modal yang diinvestasikan dalam keseluruhan aktiva untuk menghasilkan laba. ROA digunakan sebagai proksi dari kinerja keuangan karena dapat menunjukkan seberapa besar laba bersih yang diperoleh perusahaan diukur dari nilai aktivanya. Nilai ROA yang tinggi menunjukkan bahwa operasional perusahaan berjalan dengan efektif dan perusahaan berada dalam posisi yang menguntungkan, sehingga menarik perhatian para investor untuk masuk ke dalam perusahaan. Yuniasih dan Wirakusuma (2009) menyatakan bahwa ROA berpengaruh positif terhadap nilai perusahaan, sedangkan Hermawan dan Maf'ulah (2014) menyatakan bahwa kinerja keuangan (ROA) tidak berpengaruh secara signifikan terhadap nilai perusahaan.

Hasil penelitian terdahulu yang tidak konsisten mengindikasikan terdapat faktor lain yang ikut memoderasi hubungan pengungkapan CSR dan kinerja keuangan pada nilai perusahaan, salah satunya yaitu kepemilikan asing. Perusahaan dengan kepemilikan asing didalamnya lebih memerhatikan isu-isu sosial dan lingkungan yang berkembang ditambah dengan keahliannya dalam mengelola CSR serta administrasinya. Keberanian dalam mengambil risiko yang diimbangi dengan kemampuan, keahlian, pengetahuan dan kecanggihan teknologi yang dimiliki menjadi nilai tambah investor asing karena dengan sifat risk tasking tersebut diharapkan dapat menghasilkan laba yang tinggi pula. Kepemilikan asing 
Ni Made Muliastari Rahayu dan I Gst Ayu Eka Damayanthi. Pengaruh ...

dapat membagikan pengetahuan dan keahliannya agar perusahaan memiliki kinerja yang baik sehingga dapat meningkatkan nilai perusahaan dan memberikan dampak positif secara berkelanjutan. Salah satu caranya yaitu dengan meningkatkan CSR ataupun dengan meyakinkan masyarakat dengan visi dan misi yang jelas. Sissandhy (2014) menyatakan bahwa kepemilikan asing berpengaruh signifikan terhadap nilai perusahaan, kepemilikan asing juga berpengaruh signifikan terhadap CSR. Astuti (2014) juga menyatakan bahwa kepemilikan asing berpengaruh positif signifikan terhadap kinerja keuangan baik secara langsung maupun tidak langsung.

Berdasarkan fenomena tersebut, maka dapat dibuat rumusan masalah yang diteliti dalam penelitin ini yaitu apakah corporate social responsibility disclosure dan kinerja keuangan berpengaruh positif pada nilai perusahaan? Apakah kepemilikan asing memperkuat pengaruh CSR Disclosure dan kinerja keuangan pada nilai perusahaan? Tujuan dari penelitian ini adalah untuk membuktikan secara empiris dan menjelaskan rumusan masalah di atas.

Terdapat dua manfaat dari penelitian ini, yaitu manfaat teoretis dan manfaat praktis. Manfaat teoretis dalam penelitian ini adalah untuk menambah studi literature mengenai kemampuan kepemilikan asing dalam memodersi pengaruh corporate social responsibility disclosure dan kinerja keuangan pada nilai perusahaan yang dihubungkan dengan pengetahuan teoritis, khususnya teoriteori yang berkaitan dengan nilai perusahaan yaitu teori stakeholder, teori legitimasi, dan teori sinyal. Manfaat praktis dari penelitian ini adalah memberikan informasi kepada perusahaan dan investor mengenai faktor-faktor yang dapat 
memengaruhi nilai perusahaan. Penelitian ini juga diharapkan dapat digunakan oleh regulator sebagai pertimbangan dalam membuat regulasi terkait dengan pengungkapan CSR, kinerja keuangan, dan tata cara berinvestasi bagi investor asing.

Stakeholder merupakan pemangku kepentingan yang dapat memengaruhi atau dipengaruhi oleh berbagai keputusan perusahaan. Terkait dengan pengungkapan yang dilakukan perusahaan, stakeholder merupakan salah satu kelompok yang dipertimbangkan manajemen perusahaan dalam mempublikasikan suatu informasi pada laporan perusahaan. Stakeholder dapat membantu manajemen untuk dapat menciptakan nilai perusahaan yang tinggi akibat dari aktivitas yang dilakukan. Perusahaan juga dapat meminimalisir kerugian yang mungkin muncul kepada stakeholder melalui pelaksanaan aktivitas yang dapat memberikan manfaat kepada stakeholder. Perusahaan yang berhubungan baik dengan stakeholder-nya berkeinginan untuk membangun kerangka kerja yang responsif (Freeman dan McVea, 2001). Teori stakeholder menjelaskan bahwa perusahaan bukanlah entitas yang hanya beroperasi untuk kepentingan sendiri namun harus memberikan manfaat bagi stakeholder-nya. Perusahaan hidup di lingkungan masyarakat dan tentunya segala aktivitas yang dilakukan oleh perusahaan memiliki dampak terhadap sosial dan lingkungan di sekitarnya, sehingga praktik pengungkapan CSR penting bagi perusahaan dalam menjamin kelangsungan hidup perusahaan.

Kelangsungan hidup perusahaan diperoleh dari kepercayaan yang diberikan masyarakat terhadap aktivitas yang dilakukan perusahaan. Teori 
Ni Made Muliastari Rahayu dan I Gst Ayu Eka Damayanthi. Pengaruh ...

legitimasi menyatakan bahwa perusahaan harus menjalankan aktivitas operasinya berdasarkan norma dan nilai-nilai yang berlaku agar dapat diterima di masyarakat. Perusahaan akan mencari cara untuk menjamin aktivitas mereka tidak melampaui batas dan mematuhi norma yang berlaku di masyarakat. Antara pihak perusahaan dengan masyarakat telah dibuat kontrak sosial, dengan konsekuensi apabila perusahaan melanggar isi kontrak tersebut maka akan mengancam kelangsungan hidup perusahaan (Jupe, 2005). Dengan demikian, perusahaan akan melaporkan aktivitasnya secara sukarela apabila hal tersebut dianggap manajemen dapat memberikan manfaat kepada masyarakat, terutama perusahaan. Segala aktivitas yang dilakukan perusahaan pasti melibatkan lingkungan di sekitar tempat perusahaan tersebut beroperasi. Hal tersebut akan menimbulkan dampak positif maupun negatif, sehinga perusahaan diharapkan dapat mempertanggungjawabkan dampak dari aktivitas yang dilakukannya. Salah satunya caranya adalah melalui pelaksanaan aktivitas CSR. Masyarakat akan memberikan reaksi positif terhadap perusahaan karena pengungkapan aktivitas CSR menunjukkan tingkat kepatuhan suatu perusahaan seperti kepatuhan terhadap norma-norma yang berlaku, serta harapan-harapan publik kepada perusahaaan tersebut (Branco dan Rodrigues, 2008).

Informasi tentang perusahaan banyak diketahui oleh pihak internal, misalkan informasi mengenai kegiatan-kegiatan perusahaan, operasi perusahaan dan prospek perusahaan ke depannya, sehingga menimbulkan asimetri informasi. Teori sinyal mendorong perusahaan untuk membagikan informasi kepada pihakpihak eksternal untuk mengurangi asimetri informasi. Menurut Rankin et al. 
(2012: 70), signaling theory menekankan bahwa perusahaan pelapor dapat meningkatkan nilai perusahaan melalui pelaporannya. Perusahaan harus memberikan sinyal yang memiliki kekuatan informasi yang nantinya dapat mengubah penilaian pihak eksternal perusahaan. Pengumuman informasi yang dipublikasikan perusahaan dapat menjadi sinyal bagi stakeholder, terutama investor sebagai pertimbangan untuk mengambil keputusan investasi. Jika informasi yang diumumkan bernilai positif dan mempunyai nilai tambah, maka diharapkan investor akan bereaksi dengan cepat saat pengumuman informasi tersebut. Sinyal yang diberikan investor dapat berupa promosi ataupun informasi bahwa perusahaan tersebut lebih baik daripada perusahaan lain. Informasi yang dapat diberikan perusahaan kepada pihak eksternal salah satunya adalah laporan tahunan perusahaan. Informasi yang menjadi pedoman untuk pemegang saham dan calon investor adalah informasi mengenai laba perusahaan dan pengungkapan tanggung jawab sosial perusahaan. Suatu perusahaan yang mempublikasikan laporan dengan kinerja finansial dan kinerja sosial yang tinggi, akan menjadi sinyal positif bagi stakeholder melalui pengungkapan yang dilakukan.

Corporate Social Responsibility (CSR) merupakan komitmen perusahaan untuk berkontribusi bagi pembangunan ekonomi berkelanjutan. Pengungkapan aktivitas CSR tertera dalam laporan berkelanjutan secara terpisah ataupun tercantum dalam laporan tahunan. Perusahaan mengungkapkan CSR adalah untuk pembangunan, pertahanan, serta proses legitimasi kontribusi perusahaan dari segi ekonomi dan politik. Mukhtaruddin et al. (2014) menyatakan bahwa perusahaan melaksanakan CSR bertujuan untuk meningkatkan penjualan dan citra 
Ni Made Muliastari Rahayu dan I Gst Ayu Eka Damayanthi. Pengaruh ...

perusahaan, serta menjaga reputasinya terutama di hadapan investor dan analis keuangan. Setiap perusahaan, terutama yang dalam proses produksinya memanfaatkan sumber daya alam wajib untuk melaksanakan CSR. Kewajiban tersebut telah ditetapkan dalam peraturan pemerintah, tetapi item-item CSR yang diungkapkan masih bersifat sukarela (voluntary). Oleh karena itu, perusahaan bebas untuk mengungkapkan informasi terkait aktivitas CSR yang dilaksanakan yang tidak diharuskan oleh badan penyelenggara pasar modal. Hal tersebut menyebabkan adanya keragaman dalam pengungkapan karena perbedaan filosofis manajerial dan keluasan pengungkapan informasi kepada masyarakat. Perusahaan yang menerapkan CSR harus bisa mengendalikan biaya yang dikeluarkan. Biaya tersebut harus relatif ringan namun dapat memberikan manfaat keberlanjutan. Menurut Securities Exchange Comitee (SEC) tujuan pengungkapan, yaitu: 1) Protective disclosure yang dimaksudkan sebagai upaya perlindungan terhadap investor, dan 2) Informative disclosure yang bertujuan memberikan informasi yang layak kepada pengguna laporan. Pengungkapan tersebut juga dijadikan sebagai bahan evaluasi akibat dari aktivitas yang dilakukan perusahaan kepada masyarakat dan lingkungann. Akibat dari pengungkapan yang dilakukannya, perusahaan akan memperoleh manfaat positif yakni, perhatian, kepercayaan, dan dukungan dari masyarakat dengan pengungkapan tanggung jawab sosial. Bayoud dan Kavanagh (2012) juga mengungkapkan manfaat utama mengungkapkan CSR adalah terjadinya peningkatan reputasi perusahaan dan kinerja keuangan.

Kinerja keuangan adalah pencapaian prestasi kerja oleh perusahaan dalam periode tertentu yang tercantum dalam laporan keuangan. Simons (2000) 
menyatakan bahwa agar tujuan kinerja dapat tercapai, manajer harus merancang ukuran-ukuran hasil yang diinginkan. Hasil evaluasi terhadap kinerja perusahaan menjadi acuan bagi manajemen untuk memperbaiki kinerja periode berikutnya. Pengukuran kinerja juga menjadi landasan dalam memberikan reward and punishment terhadap anggota perusahaan yang berpartisipasi dalam pencapaian kinerja tersebut. Keberhasilan perusahaan dapat dilihat apabila standar dan tujuan yang telah ditentukan dapat tercapai. Penilaian kinerja keuangan dapat menggunakan beberapa alat analisis, salah satunya analisis rasio keuangan. Metode analisis rasio dapat menjelaskan baik buruknya posisi keuangan suatu perusahaan, juga kekuatan dan kelemahan keuangan perusahaan. Analisis rasio yang digunakan salah satunya yaitu rasio profitabilitas. Rasio profitabilitas memperlihatkan tinggi rendahnya laba yang dihasilkan perusahaan selama periode tertentu. Rasio profitabilitas yang digunakan untuk menganalisis kinerja perusahaan adalah Return On Asset (ROA). ROA yang tinggi menunjukkan semakin efektifnya pengelolaan aset yang dimiliki perusahaan dalam menghasilkan laba. Semakin tinggi rasio keuangan sebagai proksi kinerja keuangan, maka semakin tinggi pula harga saham perusahaan yang menjadi tolok ukur nilai perusahaan (Ball and Brown, 1968).

Kepemilikan asing adalah perseorangan, badan usaha, maupun institusi yang menanamkan modalnya ke sebuah perusahaan di negara lain. Perusahaan yang dipilih oleh investor asing memperoleh keunggulan dibandingkan perusahaan yang tidak memiliki kepemilikan asing, karena investor asing dilatih dengan baik oleh perusahaan induknya dalam bidang akuntansi. Selain itu, 
Ni Made Muliastari Rahayu dan I Gst Ayu Eka Damayanthi. Pengaruh ...

perusahaan akan mempunyai keunggulan dalam sistem informasi yang berguna untuk pemenuhan kebutuhan internal perusahaan dan perusahaan induknya. Dengan demikian, terdapat kemungkinan adanya peningkatan permintaan dari konsumen, supplier, dan masyarakat pada perusahaan dengan kepemilikan asing. Perusahaan dengan kepemilikan asing melihat bahwa legitimasi dari stakeholder tempat perusahaan beroperasi merupakan sebuah keuntungan yang dapat memberikan eksistensi dalam jangka panjang (Barkemeyer, 2007). Perusahaan dengan kepemilikan asing juga lebih memerhatikan isu-isu sosial dan lingkungan yang berkembang ditambah dengan keahliannya dalam mengelola CSR serta administrasinya. Porta et al. (1999) mengungkapkan bahwa investor asing lebih pintar dalam berinvestasi karena sudah sering menghadapi risiko yang besar dalam berinvestasi lintas negara, sehingga menyebabkan pengawasan yang dilakukan lebih tinggi. Keberanian dalam mengambil risiko juga diimbangi dengan kemampuan, keahlian, pengetahuan dan kecanggihan teknologi yang dimiliki menjadi nilai tambah investor asing karena dengan sifat risk tasking tersebut diharapkan dapat menghasilkan laba yang tinggi pula. Kepemilikan asing dapat membagikan pengetahuan dan keahliannya agar perusahaan memiliki kinerja yang baik sehingga dapat meningkatkan nilai perusahaan dan memberikan dampak positif secara berkelanjutan

Nilai perusahaan menjadi tolok ukur bagi stakeholder untuk mengetahui baik buruknya citra perusahaan. Theory of the firm menyatakan bahwa tujuan utama perusahaan yaitu memaksimalkan nilai perusahaan (Salvatore, 2005). Investor akan lebih tertarik pada perusahaan dengan citra yang baik serta 
menguntungkan sehingga bersedia menanamkan modalnya di perusahaan tersebut. Semakin banyak investor yang menanamkan modalnya di perusahaan tersebut, maka semakin tinggi harga saham sehingga nilai perusahaan akan meningkat. Perusahaan yang memiliki nilai tinggi lebih dipercaya oleh masyarakat sehingga aktivitas perusahaan dapat diterima dan kelangsungan hidup perusahaan dapat terjamin.

Berdasarkan penjelasan di atas, maka hipotesis dalam penelitian ini adalah corporate social responsibility disclosure berpengaruh positif pada nilai perusahaan $\left(\mathrm{H}_{1}\right)$, kinerja keuangan berpengaruh positif pada nilai perusahaan $\left(\mathrm{H}_{2}\right)$, kepemilikan asing memperkuat pengaruh corporate social responsibility disclosure pada nilai perusahaan $\left(\mathrm{H}_{3}\right)$, serta kepemilikan asing memperkuat pengaruh kinerja keuangan pada nilai perusahaan $\left(\mathrm{H}_{4}\right)$.

\section{METODE PENELITIAN}

Penelitian ini bertujuan untuk mengetahui hubungan dua variabel atau lebih sehingga desain penelitian yang digunakan adalah pendekatan kuantitatif berbentuk asosiatif. Penelitian ini ditujukan untuk menjawab rumusan masalah tentang pengaruh corporate social responsibility disclosure dan kinerja keuangan pada nilai perusahaan dengan kepemilikan asing sebagai variabel moderasi. Penelitian ini menggunakan kajian teoretis serta kajian empiris untuk menjawab rumusan masalah penelitian. Proses analisis teori dan penelitian terdahulu akan menghasilkan dugaan sementara, yaitu hipotesis penelitian. Hipotesis yang telah disusun nantinya akan diuji untuk mengambil kesimpulan penelitian. 
Ni Made Muliastari Rahayu dan I Gst Ayu Eka Damayanthi. Pengaruh ...

Lokasi penelitian dilakukan pada perusahaan manufaktur yang terdaftar di Bursa Efek Indonesia (BEI) tahun 2014-2016. Objek pada penelitian ini adalah nilai perusahaan pada perusahaan manufaktur yang terdaftar di BEI tahun 20142016. Terdapat tiga jenis variabel yang digunakan dalam penelitian ini yaitu variabel independen, variabel dependen, dan variabel moderasi. Variabel independen dalam penelitian ini adalah corporate social responsibility discolusre $\left(\mathrm{X}_{1}\right)$ dan kinerja keuangan $\left(\mathrm{X}_{2}\right)$, variabel dependen dalam penelitian ini adalah nilai perusahaan $(\mathrm{Y})$, sedangkan variabel moderasi dalam penelitian ini adalah kepemilikan asing $\left(\mathrm{X}_{3}\right)$.

Nilai perusahaan dapat dikatakan juga nilai pasar karena apabila terjadi peningkatan harga saham perusahaan, maka kemakmuran pemegang saham juga meningkat. Nilai perusahaan dapat dihitung dengan menggunakan Tobin's Q. Perhitungannya menggunakan rumus:

$\mathrm{Q}=\frac{(E M V+D)}{(E B V+D)}$

Keterangan :

$\mathrm{Q}=$ Nilai perusahaan

$\mathrm{EMV}=$ Nilai pasar ekuitas (closing price $\times$ jumlah saham beredar)

EBV = Nilai buku dari total ekuitas (total aktiva-total hutang)

$\mathrm{D} \quad=$ Nilai buku dari total hutang

Corporate social responsibility disclosure merupakan pengungkapan informasi yang berkaitan dengan tanggung jawab sosial yang dilakukan perusahaan yang tercantum pada laporan tahunan ataupun laporan berkelanjutan secara terpisah. Pengukuran CSR mengacu pada CSRDI (Corporate Social Responsibility Disclosure Index) berdasarkan Global Reporting Initiative (GRI) versi 4.0. Rumus perhitungan CSRDI sebagai berikut: 
$\mathrm{CSRDI}_{\mathrm{j}}=\frac{\sum x i j}{n}$

Keterangan:

$\mathrm{CSRDI}_{\mathrm{j}}=$ Corporate Social Responsibility Disclosure Index

$\sum \mathrm{X}_{\mathrm{ij}} \quad=$ Jumlah pengungkapan

$\mathrm{n} \quad=$ Item pengungkapan CSRDI

Kinerja keuangan merupakan prestasi kerja yang telah dicapai oleh perusahaan dalam suatu periode tertentu dan tertuang pada laporan keuangan perusahaan yang bersangkutan. Kinerja keuangan diukur dengan Return On Asset (ROA) untuk mengetahui seberapa besar laba atau rugi bersih yang diperoleh dari seluruh kekayaan yang dimiliki perusahaan. ROA diformulasikan sebagai berikut: $R O A=\frac{E A T}{\text { total aktiva }} \times 100 \%$

Kepemilikan asing diketahui melalui besarnya persentase saham yang dimiliki oleh investor asing yang tercantum dalam laporan keuangan pada tahun yang bersangkutan. Rumus perhitungan kepemilikan asing adalah sebagai berikut: Kepemilikan asing $=\frac{\text { Jumlah saham yang dimiliki oleh pihak asing }}{\text { Total saham yang beredar }} \times 100 \%$

Populasi dalam penelitian ini berjumlah 140 perusahaan manufaktur yang terdaftar di Bursa Efek Indonesia (BEI) tahun 2014-2016. Sampel dalam penelitian ini ditentukan melalui teknik purposive sampling, yakni teknik penentuan sampel dengan kriteria-kriteria tertentu. Kriteria-kriteria tersebut antara lain, perusahaan manufaktur yang terdaftar di BEI yang mempublikasikan laporan tahunan, menyajikan pengungkapan CSR, sahamnya ada dimiliki oleh pihak asing, dan tidak mengalami kerugian selama periode pengamatan. Selama periode pengamatan, terdapat 25 perusahaan manufaktur yang tidak mempublikasikan laporan tahunan, 4 perusahaan yang tidak menyajikan pengungkapan CSR, 49 
Ni Made Muliastari Rahayu dan I Gst Ayu Eka Damayanthi. Pengaruh ...

perusahaan yang sahamnya tidak ada dimiliki oleh pihak asing, dan 32 perusahaan yang mengalami kerugian. Berdasarkan data tersebut, maka jumlah sampel yang digunakan dalam penelitian ini sebesar 90 selama tiga tahun pengamatan.

Metode observasi non partisipan merupakan metode pengumpulan data yang digunakan dalam penelitian ini. Peneliti tidak ikut terlibat secara langsung, hanya sebagai pengamat independen (Sugiyono, 2017:146). Penelitian ini menggunakan data kuantitatif berupa laporan tahunan perusahaan manufaktur yang terdaftar di BEI tahun 2014-2016. Data dalam penelitian ini diperoleh dari laporan tahunan perusahaan manufaktur yang terdaftar di Bursa Efek Indonesia tahun 2014-2016 dengan mengakses situs www.idx.co.id.

Teknik analisis data yang digunakan adalah analisis statistik deskriptif, uji asumsi klasik, uji Moderated Regression Analysis (MRA), koefisien determinasi $\left(\mathrm{R}^{2}\right.$ ), uji hipotesis (uji t), serta uji kelayakan model (uji F). Uji Moderated Regression Analysis (MRA) digunakan untuk menentukan hubungan antara dua variabel yang dipengaruhi oleh variabel moderasi. Rumus persamaan regresinya yaitu sebagai berikut:

$Y=\alpha+\beta_{1} X_{1}+\beta_{2} X_{2}+\beta_{3} X_{3}+\beta_{4} X_{1} X_{3}+\beta_{5} X_{2} X_{3}+\varepsilon$

Keterangan :

Y : Nilai Perusahaan

A : Konstanta

$\mathrm{X}_{1} \quad$ : Corporate Social Responsibility Disclosure

$\mathrm{X}_{2} \quad$ : Kinerja Keuangan

$\mathrm{X}_{3} \quad$ : Kepemilikan Asing

$\mathrm{X}_{1} \mathrm{X}_{3}$ : Interaksi antara Corporate Social Responsibility Disclosure dan Kepemilikan Asing

$\mathrm{X}_{2} \mathrm{X}_{3} \quad$ : Interaksi antara Kinerja Keuangan dan Kepemilikan Asing

$\beta_{1}-\beta_{3}:$ Koefisien regresi

$\varepsilon \quad$ : Variabel pengganggu 


\section{HASIL DAN PEMBAHASAN}

Berdasarkan kriteria penentuan sampel diperoleh 90 perusahaan manufaktur sebagai sampel penelitian untuk dianalisis. Karakteristik variabel penelitian dapat dilihat dari hasil pengujian statistik deskriptif pada Tabel 1.

Tabel 1.

Statistik Deskriptif Variabel Penelitian

\begin{tabular}{|c|c|c|c|c|c|}
\hline & $\mathbf{N}$ & Minimum & Maximum & Mean & $\begin{array}{c}\text { Std. } \\
\text { Deviation }\end{array}$ \\
\hline CSRD & 90 & .10 & .53 & .2409 & .08669 \\
\hline Kinerja Keuangan & 90 & .00 & .94 & .1179 & .15299 \\
\hline Kepemilikan Asing & 90 & .08 & .93 & .5179 & .25276 \\
\hline Nilai Perusahaan & 90 & .50 & 18.64 & 2.3251 & 3.54555 \\
\hline Valid N (listwise) & 90 & & & & \\
\hline
\end{tabular}

Berdasarkan data di atas, nilai mean variabel corporate social responsibility disclosure sebesar 0,2409, standar deviasi sebesar 0,08669, nilai minimum sebesar 0,10 dan nilai maksimum sebesar 0,53. Variabel kinerja keuangan memiliki nilai mean sebesar 0,1179 , standar deviasi sebesar 0,15299 , nilai minimum sebesar 0,00 , dan nilai maksimum sebesar 0,94 . Variabel kepemilikan asing memiliki nilai mean sebesar 0,5179, standar deviasi sebesar 0,25276, nilai minimum sebesar 0,08 , dan nilai maksimum sebesar 0,93 persen. Variabel nilai perusahaan memiliki nilai mean sebesar 2,3251, standar deviasi sebesar 3,54555, nilai minimum sebesar 0,50 , dan nilai maksimum sebesar 18,64.

Uji asumsi klasik terdiri atas uji normalitas, uji multikoleniaritas, uji autokorelasi, dan uji heteroskedastisitas. Uji normalitas digunakan untuk menguji apakah dalam model regresi, variabel dependen dan variabel independen berdistribusi normal atau tidak. Penelitian ini menggunakan uji KolmogorovSmirnov. Berdasarkan hasil uji normalitas, diperoleh nilai Asymp. Sig. (2-tailed) 
Ni Made Muliastari Rahayu dan I Gst Ayu Eka Damayanthi. Pengaruh ...

sebesar 0,821 >0,05. Hal ini menunjukkan bahwa data pada model regresi berdistribusi normal.

Uji multikolinearitas dilakukan untuk mengetahui apakah dalam model regresi terdapat korelasi antar variabel independen. Hasil uji multikolinearitas menunjukkan bahwa nilai tolerance untuk setiap variabel lebih besar dari 0,10 dan nilai VIF lebih kecil dari 10. Oleh karena itu, dapat disimpulkan bahwa tidak adanya multikolinearitas antar variabel bebas dalam moderasi regresi. Uji autokorelasi dilakukan untuk mengetahui apakah terdapat korelasi diantara anggota-anggota dari serangkaian pengamatan yang tersusun dalam rangkaian waktu. Berdasarkan hasil uji autokorelasi menunjukkan nilai Durbin-Watson sebesar 1,898 dengan jumlah variabel sebanyak $5(k=5)$, maka nilai $d_{L}=1,542$ dan $d_{U}=1,776$, sehingga $4-d_{L}=2,458$ dan $4-d_{U}=2,224$. Nilai DW 1,898 $>d_{U}$ yaitu 1,776 dan DW $1,898<4-\mathrm{d}_{\mathrm{U}}$ yaitu 2,224, maka model regresi tidak mengandung autokorelasi.

Uji heteroskedastisitas bertujuan untuk mengetahui ada atau tidaknya ketidaksamaan varians dari residual pengamatan satu ke pengamatan lainnya. Hasil uji heteroskedastisitas menunjukkan bahwa nilai signifikansi dari masingmasing variabel sebesar 0,$293 ; 0,600 ; 0,506 ; 0,393$ dan 0,386 . Nilai tersebut lebih besar dari tingkat signifikansi 0,05 yang menunjukkan bahwa model regresi yang digunakan dalam penelitian bebas dari gejala heteroskedastisitas. 
Tabel 2.

Hasil Uji Moderated Regression Analysis (MRA)

\begin{tabular}{|c|c|c|c|c|c|c|}
\hline \multicolumn{2}{|c|}{ Model } & \multicolumn{2}{|c|}{$\begin{array}{c}\text { Unstandardized } \\
\text { Coefficients }\end{array}$} & \multirow{2}{*}{$\begin{array}{c}\begin{array}{c}\text { Standardized } \\
\text { Coefficients }\end{array} \\
\text { Beta }\end{array}$} & \multirow[t]{2}{*}{$\mathbf{T}$} & \multirow[t]{2}{*}{ Sig. } \\
\hline & & $\overline{\mathbf{B}}$ & $\begin{array}{l}\text { Std. } \\
\text { Error }\end{array}$ & & & \\
\hline \multirow[t]{10}{*}{1} & (Constant) & 1.120 & .111 & & 10.073 & .000 \\
\hline & CSRD & .861 & .176 & .270 & 4.904 & .000 \\
\hline & Kinerja Keuangan & .217 & .288 & .087 & .754 & .453 \\
\hline & Kepemilikan Asing & .804 & .101 & .694 & 7.963 & .000 \\
\hline & $\begin{array}{l}\text { Interaksi antara CSRD dan } \\
\text { Kepemilikan Asing }\end{array}$ & -5.208 & 1.209 & -.102 & -4.308 & .000 \\
\hline & $\begin{array}{l}\text { Interaksi antara Kinerja } \\
\text { Keuangan dan } \\
\text { Kepemilikan Asing }\end{array}$ & .167 & .720 & .007 & .231 & .818 \\
\hline & $\mathrm{R}^{2}$ & & & & & 0,982 \\
\hline & Adjusted $\mathrm{R}^{2}$ & & & & & 0,981 \\
\hline & F Statistik & & & & & 914,298 \\
\hline & F Signifikansi & & & & & 0,000 \\
\hline
\end{tabular}

Sumber: Data diolah, 2017

Berdasarkan Tabel 2, persamaan regresi yang terbentuk adalah sebagai berikut:

$Y=1,120+0,270 X_{1}+0,087 X_{2}+0,694 X_{3}-0,102 X_{1} X_{3}+0,007 X_{2} X_{3}+\varepsilon$

Nilai konstanta sebesar 1,120 memiliki arti apabila variabel independen corporate social responsibility disclosure, kinerja keuangan, kepemilikan asing, interaksi corporate social responsibility disclosure dengan kepemilikan asing, dan interaksi kinerja keuangan dengan kepemilikan asing bernilai konstan, maka variabel dependen nilai perusahaan akan naik sebesar 1,120. Nilai koefisien variabel corporate social responsibility disclosure (CSRD) sebesar 0,270 artinya jika nilai CSRD meningkat satu satuan, maka variabel nilai perusahaan meningkat sebesar 0,270 dengan asumsi variabel independen lain konstan. Nilai koefisien variabel kinerja keuangan sebesar 0,087 artinya jika nilai kinerja keuangan 
Ni Made Muliastari Rahayu dan I Gst Ayu Eka Damayanthi. Pengaruh ...

meningkat satu satuan, maka variabel nilai perusahaan meningkat sebesar 0,087 dengan asumsi variabel independen lain konstan.

Nilai koefisien variabel kepemilikan asing sebesar 0,694 artinya jika nilai kepemilikan asing meningkat satu satuan, maka variabel nilai perusahaan meningkat sebesar 0,694 dengan asumsi variabel independen lain konstan. Nilai koefisien moderasi $\left(\beta_{4}\right)$ interaksi antara variabel corporate social responsibility disclosure dengan variabel kepemilikan asing sebesar -0,102 artinya efek apabila moderasi kepemilikan asing meningkat satu satuan maka pengaruh corporate social responsibility disclosure pada nilai perusahaan menurun (berkurang) sebesar 0,102 dengan asumsi variabel independen lainnya bernilai konstan. Nilai koefisien moderasi $\left(\beta_{5}\right)$ interaksi antara variabel kinerja keuangan dengan variabel kepemilikan asing sebesar 0,007 artinya apabila moderasi kepemilikan asing meningkat satu satuan maka pengaruh positif kinerja keuangan pada nilai perusahaan meningkat (bertambah) sebesar 0,007 dengan asumsi variabel independen lainnya bernilai konstan.

Nilai Adjusted $\mathrm{R}^{2}$ yang ditunjukkan pada Tabel 2 sebesar 0,981 memiliki arti 98,1\% variansi dari variabel nilai perusahaan mampu dijelaskan oleh variansi variabel corporate social responsibility disclosure, kinerja keuangan, dan kepemilikan asing, serta interaksi antara corporate social responsibility disclosure dengan kepemilikan asing dan interaksi antara kinerja keuangan dengan kepemilikan asing, sedangkan sisanya 1,9\% dijelaskan oleh faktor lain yang tidak dimasukkan ke dalam model. 
Berdasarkan hasil analisis pada Tabel 2, menunjukkan nilai $\mathrm{F}$ hitung sebesar 914,298 dan nilai signifikansi $\mathrm{F}$ atau p-value sebesar 0,000 lebih kecil dari $\alpha=0,05$. Hal ini menunjukkan bahwa CSRD, kinerja keuangan, kepemilikan asing, interaksi antarta CSRD dengan kepemilikan asing, dan interaksi antara kinerja keuangan dengan kepemilikan asing berpengaruh secara simultan pada nilai perusahaan. Jadi dapat disimpulkan bahwa model layak digunakan.

Tabel 2 menunjukkan bahwa variabel corporate social responsibility disclosure memiliki koefisien sebesar 0,270 dengan nilai Sig. t sebesar 0,000< 0,05, maka hipotesis pertama diterima. Hal ini berarti corporate social responsibility disclosure berpengaruh positif pada nilai perusahaan. Pengungkapan aktivitas CSR akan menjadi suatu sinyal bagi masyarakat yang nantinya akan menjadi nilai tambah dan mengubah penilaian negatif masyarakat terhadap perusahaan. Perusahaan akan mendapatkan legitimasi dari masyarakat sehingga aktivitas dan kinerja perusahaan dapat diterima. Perusahaan yang memiliki kinerja lingkungan dan sosial yang baik serta diungkapkan secara lebih luas menjadi sinyal positif bagi investor dan direspon melalui peningkatan harga saham. Hal tersebut dikarenakan investor lebih berminat pada perusahaan yang memiliki citra yang baik di masyarakat, karena semakin baik citra perusahaaan, loyalitas konsumen semakin tinggi sehingga dalam waktu lama penjualan perusahaan akan membaik. Dengan demikian, para investor akan tertarik untuk berinvestasi pada perusahaan tersebut karena legitimasi masyarakat kepada perusahaan menjadi faktor yang strategis bagi perkembangan perusahaan ke depannya, hal inilah yang menyebabkan nilai perusahaan meningkat. Hasil 
Ni Made Muliastari Rahayu dan I Gst Ayu Eka Damayanthi. Pengaruh ...

penelitian ini sejalan dengan penelitian yang dilakukan oleh Putri (2016), Nurani (2015), Putra (2015), Astiyani (2014), dan Servaes dan Tamayo (2013) yang menyatakan bahwa CSR Disclosure berpengaruh positif pada nilai perusahaan.

Berdasarkan Tabel 2 dapat diketahui koefisien variabel kinerja keuangan sebesar 0,087 dengan nilai Sig. t sebesar 0,453 > 0,05, maka hipotesis kedua ditolak. Hal ini berarti kinerja keuangan tidak berpengaruh pada nilai perusahaan. Pengumuman laba yang tinggi tidak akan menyebabkan investor bereaksi dengan cepat karena sebagian besar investor memiliki sifat risk averse. Sifat tersebut menunjukkan bahwa investor takut untuk menanggung risiko terkait dengan tingkat pengembalian (return) yang akan didapatkan. Investor bereaksi lamban untuk menyerap informasi dari perusahaan yang mempublikasikan labanya karena investor lebih tertarik pada perkembangan makroekonomi dibandingkan dengan informasi pengumuman laba. Terkait dengan perolehan laba yang tinggi, tidak serta merta mencerminkan pembagian dividen yang besar, karena perusahaan dapat menggunakan sebagian laba sebagai laba ditahan untuk memperbesar sumber dana intern. Laba ditahan tersebut menyebabkan laba yang tersedia untuk pembayaran dividen semakin kecil sehingga tidak sebanding dengan risiko yang ditanggung oleh investor. Hasil penelitian ini sejalan dengan penelitian yang dilakukan oleh Hermawan dan Maf'ulah (2014) serta Tjandrakirana dan Monika (2014) yang menyatakan bahwa kinerja keuangan (ROA) tidak berpengaruh secara signifikan terhadap nilai perusahaan.

Interaksi antara corporate social responsibility disclosure dengan kepemilikan asing yang ditunjukkan pada Tabel 2 memiliki koefisien sebesar - 
0,102 dengan nilai Sig. $\mathrm{t}$ sebesar $0,000<0,05$, maka hipotesis ketiga ditolak. Hasil ini mempunyai arti bahwa kepemilikan asing memperlemah pengaruh corporate social responsibility disclosure pada nilai perusahaan. Peranan kepemilikan asing dalam perusahaan cenderung pasif, karena jenis investasi asing yang dilakukan di pasar modal Indonesia dikategorikan sebagai investasi tidak langsung sehingga tidak dapat memberikan pengaruh secara langsung terhadap perusahaan dikarenakan partisipasi asing terbatas pada saat dilakukan Rapat Umum Pemegang Saham. Investor juga tidak memiliki kontrol pada pengelolaan perusahaan sehari-hari karena investor tidak dapat hadir secara fisik. Investasi tidak langsung tersebut menunjukkan bahwa investor bertujuan untuk memperoleh hasil yang maksimal dengan waktu yang tidak terlalu lama. Biayabiaya sosial sebagai wujud pelaksanaan CSR perusahaan akan mempengaruhi return yang akan diterima perusahaan. Semakin banyak aktivitas dan pengungkapan CSR yang dilakukan perusahaan, maka biaya yang dikeluarkan akan semakin besar sehingga menurunkan profit perusahaan. Hasil penelitian ini sejalan dengan penilitian Sari dan Suaryana (2013) yang menyatakan bahwa kehadiran pemodal asing hanya sebatas untuk mengejar keuntungan dan kurang memperhatikan kondisi sosial masyarakat di sekitar perusahaan tersebut. Investor asing hanya tertarik dengan tingkat pengembalian dari saham yang mereka tanam di perusahaan tersebut (Idzni dan Purwanto, 2017).

Interaksi kinerja keuangan dengan kepemilikan asing memiliki koefisien sebesar 0,007 dengan nilai Sig. t sebesar 0,818 > 0,05, maka hipotesis keempat ditolak. Hasil ini mempunyai arti bahwa kepemilikan asing tidak memoderasi 
Ni Made Muliastari Rahayu dan I Gst Ayu Eka Damayanthi. Pengaruh ...

pengaruh kinerja keuangan pada nilai perusahaan. Menurut Liang et al. (2013) hal tersebut dikarenakan adanya gap dalam hal transfer of knowledge dan teknologi yang memengaruhi operasional dan manajemen stratejik dari pihak asing tersebut ke pekerja lokal. Hal itu dapat terjadi karena adanya faktor jarak antara prinsipal dan agen, perbedaan bahasa, budaya, regulasi, serta pengawasan. Investor asing juga seringkali tidak rela melepaskan semua rahasia perusahaan mereka terutama dalam alih teknologi sehingga menyebabkan angka ketergantungan perusahaan terhadap investor asing masih tetap tinggi. Peranan kepemilikan asing dalam perusahaan juga cenderung pasif, karena jenis investasi asing yang dilakukan di pasar modal Indonesia dikategorikan sebagai investasi tidak langsung sehingga tidak dapat memberikan pengaruh secara langsung terhadap kinerja perusahaan dikarenakan partisipasi asing terbatas pada saat dilakukan Rapat Umum Pemegang Saham. Hasil penelitian ini sejalan dengan penelitian yang dilakukan oleh Winata (2012) yang menyatakan bahwa kepemilikan asing tidak memiliki pengaruh terhadap kinerja perusahaan. Penelitian Nuraini (2016) juga menyatakan bahwa kepemilikan saham asing tidak berpengaruh terhadap nilai perusahaan.

Terdapat dua implikasi penelitian dalam penelitian ini, yaitu implikasi teoretis dan implikasi praktis. Implikasi teoretis dalam penelitian ini adalah ditemukan bahwa corporate social responsibility disclosure berpengaruh positif pada nilai perusahaan. Sejalan dengan teori stakeholder, bahwa perusahaan bukanlah entitas yang hanya beroperasi untuk kepentingan sendiri namun harus memberikan manfaat bagi stakeholder-nya. Perusahaaan juga harus memerhatikan isu sosial dan lingkungan, tidak beraktivitas hanya untuk memperoleh laba. Teori 
legitimasi menyatakan bahwa perusahaan yang mengungkapkan aktivitas CSR akan mendapatkan kepercayaan dan dukungan dari masyarakat sehingga aktivitas perusahaan dapat diterima di lingkungannya. Teori sinyal juga menjelaskan bahwa perusahaan harus membagikan informasi yang dapat memberikan nilai tambah perusahaan kepada pihak-pihak eksternal. Informasi tersebut dapat menjadi sinyal positif sehingga stakeholder akan memberikan legitimasi dan kepercayaan pada perusahaan. Apabila keinginan stakeholder terpenuhi, maka akan berdampak pada meningkatnya nilai perusahaan melalui kenaikan harga saham. Implikasi praktis penelitian ini adalah bagi perusahaan, investor dan regulator.

\section{SIMPULAN}

Simpulan yang dapat ditarik dalam penelitian ini adalah corporate social responsibility disclosure berpengaruh positif pada nilai perusahaan, kinerja keuangan tidak berpengaruh pada nilai perusahaan, kepemilikan asing memperlemah pengaruh corporate social responsibility disclosure pada nilai perusahaan, serta kepemilikan asing tidak memoderasi pengaruh kinerja keuangan pada nilai perusahaan.

Saran yang dapat diberikan adalah perusahaan sebaiknya mengadakan pendidikan dan pelatihan kepada tenaga kerja warga Negara Indonesia untuk meningkatkan keterampilan dan mengembangkan kreativitas, agar tenaga kerja yang tersedia memiliki kemampuan, terutama untuk alih teknologi dan alih keahlian, sehingga perusahaan tidak terlalu bergantung pada investor asing. 


\section{REFERENSI}

Aghashahi, Betsabeh; Zaleha, Siti; Sarli, Majid dan Mand, Abdollah Ah. 2013. Corporate Social Responsibility Reporting of Food Industry Major Players. Interdisciplinary Journal of Contemporary Research in Business, 5(2): 751-761.

Astiyani, Made Norisa. 2014. Kemampuan Corporate Governance Memoderasi Pengaruh Pengungkapan CSR pada Nilai Perusahaan. Jurnal Akuntansi Universitas Udayana, 7(1): 235-249.

Astuti, Fitria Puji. 2014. Pengaruh Kinerja Lingkungan dan Kepemilikan Asing terhadap Kinerja Keuangan. Accounting Analysis Journal, 3(4): 493-500.

Ball, R. dan P., Brown. 1993. An Empirical Evaluation of Accounting Income Numbers. Journal of Accounting Research 6: 159-178.

Barkemeyer, Ralf. 2007. Legitimacy as a Key Driver and Determinant of CSR in Developing Countries. Paper for the 2007 Marie Curie Summer School on Earth System Governance, 28 May - 06 June 2007, Amsterdam.

Bayoud, Nagib Salem dan Kavanagh, Marie. 2012. Corporate Social Responsibility Disclosure: Evidence From Libyan Managers. Global Journal Of Business Research, 6(5): 73-83.

Branco, M. C. dan Rodrigues, Lucia Lima. 2008. Faktors Influencing Social Responsibility Disclosure by Portuguese Companies. Journal of Business Ethies, 83: 685-701.

Freeman, R. E. dan McVea, J. 2001. A Stakeholder Approach To Strategic Management. In M. A. Hitt, R. E. Freeman \& J. S. Harrison (Eds.), The Blackwell Handbook Of Strategic Management. Malden, MA: Blackwell Publishers: 189-207.

Garret, Paul dan Heal, Geoffrey. 2004. Corporate Social Responsibility, An Economic and Financial Framework. Columbia Business School.

Ghaesani, Nissa Sabrina. 2016. Pengaruh Pengungkapan Corporate Social Responsibility, Profitabilitas, Ukuran Perusahaan dan Kinerja Lingkungan terhadap Nilai Perusahaan (Studi Empiris Pada Perusahaan Manufaktur yang Mengikuti PROPER dan Terdaftar di Bursa Efek Indonesia Periode 2012-2014). Skripsi Sarjana Jurusan Akuntansi Fakultas Ekonomi dan Bisnis. Universitas Muhammadiyah, Yogyakarta.

Hermawan, Sigit dan Maf'ulah, Afiyah Nurul. 2014. Pengaruh Kinerja Keuangan terhadap Nilai Perusahaan dengan Pengungkapan Corporate Social 
Responsibility sebagai Variabel Pemoderasi. Jurnal Dinamika Akuntansi, 6(2): 103-118.

Hidayat, Rafki. 2016. Kepercayaan Eropa untuk Berinvestasi di Indonesia Anjlok. http://www.bbc.com/indonesia/berita_indonesia/2016/02/160203_indonesi a_kepercayaan_investor_anjlok. Diakses 2 November 2017.

Hui, F. dan Bowrey, G. 2008. Corporate Social Responsibility Reporting in Hongkong: Case Study of Three Note-issuing Banks (2003-2006). http://ro.uow.edu.au/\%20business\%20/papers/440. Diakses 6 Januari 2018.

Idzni, Irsalina Nur dan Purwanto, Agus. 2017. Pengaruh Ketertarikan Investor Asing dan Kepemilikan Institusional terhadap Penghindaran Pajak Perusahaan. Diponegoro Journal of Accounting, 6(1): 1-12.

Jupe, Robert. 2005. Disclosure in Corporate Environmental Reports: A Test of Legitimacy Theory. Working Paper No. 91.

Liang, Q.; Xu, P. dan Jiraporn, P. 2013. Board Characteristics and Chinese Bank Performance.

Mukhtaruddin, Relasari, dan Felmina, Messa. 2014. Good Corporate Governance Mechanism, Corporate Social Responsibility Disclosure on Firm Value: Empirical Study on Listed Company in Indonesia Stock Exchange. International Journal of Finance \& Accounting Studies, 2(1): 135-166.

Nuraini, Selvi. 2016. Pengaruh Kepemilikan Saham Institusional dan Asing terhadap Nilai Perusahaan dengan Pengungkapan Corporate Social Responsibility sebagai Variabel Pemoderasi. Artikel Ilmiah. Jurusan Akuntansi Sekolah Tinggi Ilmu Ekonomi Perbanas, Surabaya.

Nurani, Wigati. 2015. Pengaruh Pengungkapan Corporate Social Responsibility (CSR) terhadap Nilai Perusahaan dengan Kinerja Lingkungan dan Struktur Kepemilikan Modal Asing sebagai Variabel Moderating. Skripsi Sarjana Universitas Islam Negeri Maulana Malik Ibrahim, Malang.

Porta, R. L. and Lopez-De Silanez. 1999. Corporate Ownership Around the World. Journal of Finance, 24(2): 471-578.

Putra, I.G.A.N. Bayu Darma. 2015. Pengaruh Pengungkapan Corporate Social Responsibility pada Nilai Perusahaan dengan Profitabilitas sebagai Pemoderasi. Jurnal Akuntansi Universitas Udayana, 13(2): 461-475. 
Putri, Ida Ayu Sasmika. 2016. Pengaruh Tanggung Jawab Sosial Perusahaan dan Mekanisme Tata Kelola Perusahaan terhadap Nilai Perusahaan. Jurnal Akuntansi Universitas Udayana, 15(1): 667-694.

Rankin, Michaela; Stanton, Patricia; Ferlauto, Kimberly; McGowan, Susan dan Tilling, Matthew. 2012. Contemporary Issues in Accounting. Australia: John Wiley \& Sons Australia, Ltd.

Salvatore, Dominick. 2005. Ekonomi Manajerial dalam Perekonomian Global Buku 1 Edisi Kelima. Jakarta: Salemba Empat.

Sari, Ni Luh Kade Merta dan I.G.N. Agung Suaryana. 2013. Pengaruh Pengungkapan CSR terhadap Kinerja Keuangan dengan Kepemilikan Asing sebagai Variabel Moderator. Jurnal Akuntansi Universitas Udayana, 3(2): 248-257.

Servaes, Henri dan Tamayo, Ane. 2013. The Impact of Corporate Social Responsibility on Firm Value: The Role Of Customer Awareness. Management Science, 59(5): 1045-1061.

Simons, Robert. 2000. Performance Measurement and Control System Implementing Strategy. New Jersey: Prentice Hall, Inc.

Sissandhy, Aldila Khairina. 2014. Pengaruh Kepemilikan Asing terhadap Nilai Perusahaan dengan Pengungkapan Corporate Social Responsibility sebagai Variabel Intervening. Skripsi Sarjana Jurusan Akuntansi Fakultas Ekonomika dan Bisnis Universitas Diponegoro, Semarang.

Sugiyono. 2017. Metode Penelitian Kualitatif Kuantitatif dan $R \& D)$. Bandung: Alfabeta.

Tjandrakirana, Hj. Rina dan Monika, Meva. 2014. Pengaruh Kinerja Keuangan terhadap Nilai Perusahaan pada Perusahaan Manufaktur yang Terdaftar di Bursa Efek Indonesia. Jurnal Manajemen dan Bisnis Sriwijaya, 12(1): 116.

Winata, Galih Yoga. 2012. Pengaruh Struktur Kepemilikan terhadap Kinerja Perusahaan Perbankan (Studi Empiris terhadap Perusahaan Perbankan yang Terdaftar di Bursa Efek Indonesia Periode 2007-2010). Skripsi Sarjana Jurusan Akuntansi Fakultas Ekonomi Universitas Sebelas Maret, Surakarta.

Yuniasih, Ni Wayan dan Wirakusuma, Made Gede. 2009. Pengaruh Kinerja Keuangan terhadap Nilai Perusahaan dengan Pengungkapan Corporate Social Responsibility dan Good Corporate Governance sebagai Variabel Pemoderasi. Jurnal Akuntansi dan Bisnis Media AUDI, 4 (1): 1-10. 